\title{
SHARIAH CONFORMITY DAN PROFITABILITY: APAKAH ETHICAL IDENTITY BERPENGARUH DI BANK SYARIAH?
}

\author{
Zenubia Maulida Fitria dan Sulhani* \\ Institut Agama Islam Tazkia \\ Jl. Ir. H. Djuanda No. 78 Sentul, Kota Bogor, Jawa Barat 16810 \\ Email: zenubiamaulidaf@gmail.comdan sulhani@tazkia.ac.id*
}

\begin{abstract}
This study aims to analyze the effect of ethical identity index and company size on Islamic banking performance as measured by shariah conformity and profitability (SCNP). The sample in this study were 48 Islamic banking financial reports taken from the 2014-2017 period. The data analysis method used in this study is multiple linear regression with panel data. The results of this study indicate that the ethical identity index affect shariah conformity and profitability, but company size does not affect the performance of shariah conformity and profitability. The implication of this research is that Islamic banking is expected to improve the identity of Islamic ethics through disclosures in financial reports.
\end{abstract}

Keywords: SCNP, Ethical Identity Index, Performance, Islamic Banking

\section{ABSTRAK}

Penelitian ini bertujuan untuk menganalisis pengaruh ethical identity index dan ukuran perusahaan terhadap kinerja perbankan Syariah yang diukur dengan shariah conformity and profitability (SCNP). Sampel dalam penelitian ini sebanyak 48 laporan keuangan perbankan Syariah yang diambil dari periode 2014-2017. Metode analisis data yang digunakan dalam penelitian ini adalah regresi linear berganda dengan data panel. Hasil penelitian ini menunjukkan bahwa ethical identity index berpengaruh terhadap shariahl confimity and profitability, namun ukuran perusahaan tidak berpengaruh terhadap kinerja shariah conformity and profitability. Implikasi dari penelitian ini perbankan Syariah diharapkan meningkatkan identitias etika Islam melalui pengungkapan dalam laporan keuangan.

Kata kunci: SCNP, Ethical Identity Index, Kinerja, Perbankan Syariah

\section{PENDAHULUAN}

Bank syariah didirikan dengan tujuan untuk mensyiarkan dan mengembangkan penerapan prinsip-prinsip Islam ke dalam transaksi keuangan dan perbankan (Arifin, 2006). Selain itu menurut Antonio (2001) akad yang dikembangkan dan dijalankan oleh perbankan syariah memiliki konsekuensi duniawi dan ukhrawi karena berdasarkan pada prinsip-prinsip syariah. Sehingga perbankan syariah harus senantiasa menjalankan praktikpraktik operasional perbankan yang sesuai dengan hukum syariah. Hal ini 
juga berdampak pada beragamnya pengukuran kinerja untuk perbankan syariah sehingga mampu mengukur kinerja perbankan syariah secara komprehensif. Disatu sisi perbankan syariah harus mempertahankan profitabilitasnya untuk menjamin kelangsungan usaha disisi lain perbankan syariah juga harus tetap pada koridor syariah.

Kinerja dapat diartikan sebagai aktivitas yang dapat diukur dari suatu entitas pada periode tertentu yang dapat dijadikan acuan dari keberhasilan entitas tersebut (Muhibbai \& Basri, 2017). Maka informasi mengenai kinerja dapat digunakan untuk mengukur perkembangan perusahaan dan dapat dijadikan acuan untuk menetapkan kebijakan yang akan diambil oleh perusahaan. Menurut Kuppusamy et al., (2010) pengukuran kinerja perbankan syariah harus menggunakan alat ukur yang menunjukan sisi Syariah namun juga tidak mengabaikan pengukuran kinerja keuangan yang secara umum digunakan, seperti profitabilitas. Dengan tujuan tersebut maka terdapat salah satu model pengukuran kinerja keuangan perbankan syariah yang menggabungkan indikator syariah dan konvensional, yaitu Sharia Conformity and Profitability (SCNP). Pengukuran kinerja perbankan syariah ini telah dikembangkan oleh Kuppusamy et al., (2010) dengan indikator syariah berupa rasio Sharia Conformity dan indikator konvensional berupa rasio Profitability. Dengan menggunakan SCNP model diharapkan kinerja perbankan Syariah dapat diukur secara komprehensif yang tidak hanya berfokus pada profitabilitas saja.

Kinerja perbankan Syariah dipengaruhi oleh kepercayaan nasabah terhadap produk-produk yang dikeluarkan oleh perbankan Syariah. Untuk meningkatkan kepercayaan tersebut maka perbankan Syariah harus selalu berpegang pada prinsip-prinsip Syariah dalam seluruh kegiatan operasinya. Meskipun perbankan Syariah dituntut untuk memperoleh profit yang tinggi namun perbankan syriah tidak boleh meninggalkan identitasnya sebagai perbankan yang menjalankan operasional dengan prinsip-prinsip Syariah. Identitas perbankan Syariah tersebut sangat penting untuk meyakinkan nasabah bahwa perbankan Syariah tidak semata-mata mengejar keuntungan, namun juga tetap mempertahankan identitas syariahnya dengan beroperasi sesuai dengan prinsip-prinsip Syariah.

Penilaian identitas bank Syariah dalam menjalankan operasional bisnis sesuai prinsip-prinsip Syariah dikenal dengan ethical identity index (Haniffa \& Hudaib, 2007). Selain untuk mengukur tingkat kesesuain prinsipprinsip Syariah yang dijalankan oleh perbankan syariah ethical identity index juga dapat menjadi salah satu faktor yang dapat mempengaruhi tingkat kinerja bank Syariah (Ariyanto, 2014). Identitas Etika merupakan bentuk cerminan dari kondisi, sikap, dan komitmen perusahan. Semakin baik etika maka semakin baik pula perbankan dalam beroperasi sesuai dengan nilainilai Syariah yang dipegang. Hal ini juga akan menambah citra baik dimata pemangku kepentingan. Jika demikian peningkatan citra dan reputasi akan mendorong bank syariah meningkatkan kinerjanya dan pada akhirnya tercapai kinerja keuangan perusahaan yang diharapkan.

Perbedaan penelitian ini dengan penelitian sebelumnya adalah dengan menggunakan pengukuran kinerja SCNP yang merupakan gabungan antara 
kinerja operasional Syariah dengan profitabilitas yang umum digunakan. Penelitian sebelumnya yang dilakukan oleh Ariyanto, (2014), Zaki, Sholihin, \& Barokah (2014) serta Fauziyah \& Siswantoro (2016) menguji pengaruh pengungkapan Identitas Etika terhadap kinerja keuangan perbankan syariah yang diukur menggunakan Return on Asset (ROA) dan Return on Equity (ROE). Padahal seharusnya pengukuran kinerja perbankan Syariah tidak hanya berfokus pada pengukuran profitabilitas saja dengan menggunakan rasio ROA dan ROE namun juga perlu memperhatikan apakah operasional perbankan Syariah sesuai dengan prinsip-prinsip Syariah. Berdasarkan uraian tersebut maka permasalahan dalam penelitian ini adalah bagaimana pengaruh antara EII dengan kinerja yang diukur dengan SCNP.

\section{TELAAH TEORITIS}

\subsection{CORPORATE IDENTITY}

Corporate Identity atau identitas perusahaan merupakan identitas yang membedakan antara satu perusahaan dengan perusahaan lainnya. Bertujuan sebagai penanaman citra yang dapat dijadikan sebagai cerminan kepribadian sebuah perusahaan. Konsep ini bertujuan untuk menggambarkan perwujudan perusahan yang unik dan khas agar dapat beroprasi dengan baik dan suskser di pasar sehingga dapat memberikan perbedaan dengan perusahaan lainnya (Vera Zelenović, P., \& Davidović, 2011). Menurut Berrone et al., (2007) corporate identity mendapat respon dari praktisi dan akademisi, karena diyakini memiliki pengaruh positif terhadap reputasi perusahaan. Diperkuat oleh Roberts \& Dowling (2002) yang mengatakan bahwa reputasi yang baik akan meningkatkan kemampuan perusahaan dalam mempertahankan keuntungan dari waktu ke waktu, sehingga berdampak pada peningkatan kinerja perusahaan. Maka identitas etika perusahaan dibutuhkan dalam bersaing dengan perusahaan lain sehingga menjadi salah satu faktor penting dalam strategi komunikasi perusahaan, karena hal tersebut mencerminkan rencana perusahaan yang matang. Identitas perusahaan yang baik adalah yang sejalan dengan strategi dan rencana perusahaan, sehingga menimbulkan persepsi masyarakat dan pemangku kepentingan terhadap perusahaan atau produknya. Maka corporate identity dapat dikatakan sebagai cerminan dari reputasi perusahaan.

Dalam teori legitimasi yang dikemukakan oleh Gray et al., (2001) perusahaan berusaha untuk melakukan pengelolaan perusahaan yang memiliki orientasi keberpihakan pada masyarakat, pemerintah, dan individu. Legitimasi diperoleh jika keberadaan perusahaan selaras dengan eksistensi system nilai yang ada dalam masyarakat dan lingkungan (Deegan, 2002). Sejalan dengan teori legitimasi tersebut bank syariaah memiliki karakteristik yang harus ditonjolkan dibandingkan dengan bank konvensional. Nilai-nilai yang sejalan dengan prinsip-prinsip Syariah harus menjadi identitas utama operasional perbankan Syariah yang sampai kepada masyarakat. Sehingga dalam upaya memperoleh legitimasi masyarkat bank Syariah mampu 
mempertahankan identitasnya sebagai perusahaan yang berlandaskan pada nilai-nilai Islam.

\section{ETHICAL IDENTITY INDEX}

Ethical Identity Index (EII) adalah metode yang digunakan untuk menilai perbandingan antara informasi yang seharusnya diungkapkan dan informasi yang telah diungkapkan bank syariah pada laporan tahunan yang berdasarkan nilai-nilai etika Islam. Haniffa \& Hudaib (2007) berpendapat bahwa terdapat delapan dimensi pengungkapan bank syariah yang harus diungkapkan berdasarkan lima nilai etika Islam yang terkandung dalam laporan tahunan bank syariah, antara lain adalah: 1).Filosofi dan nilai yang mendasari Bank Syariah. Filosofi dan prinsip yang mendasari perbankan syariah adalah ketentuan syariah dan aktivitas operasional yang berbasis etika dengan tambahan fungsi sosial (Haniffa \& Hudaib, 2007; Fauziyah \& Siswantoro, 2016; Hameed \& Mohamed, 2016). Setiap bank syariah dalam menjalankan perilaku bisnisnya, bukan hanya memiliki tanggung jawab terhadap kegiatan keuangan saja tapi juga tidak terlepas dari moral dan tanggung jawab. Hal ini juga harus didukung oleh setiap elemen dalam bank syariah. Seperti yang diungkapkan oleh Haniffa \& Hudaib (2007) pelaku yang mengelola bank syariah harus memiliki ilmu dan kompetensi yang relevan dalam bidang perbankan syariah. Dengan demikian filosofi dan nilai yang mendasari bank syariah dapat tercapai dengan baik.

Nilai kedua dari EII adalah Penyediaan produk dan jasa bebas bunga. Perbankan syariah yang bebas dari riba memiliki tanggung jawab dalam mengeluarkan produk dan jasa. Bank syariah harus memberikan informasi kepada setiap pemangku kepentingan bahwa produk dan jasa yang dikeluarkan tidak mengandung unsur riba. Selain itu bank syariah juga harus memastikan bahwa mekanisme setiap produk dan jasa telah sesuai dengan ketentuan syariah. Nilai ketiga dari EII adalah Pembatasan Bank Syariah kepada transaksi-transaksi yang diperbolehkan Syariah. Transaksi atau akad yang sah menjadi salah satu poin utama yang sangat penting bagi perbankan syariah karena kegiatannya sebagian besar berkaitan dengan transaksi dan jasa keuangan. Dengan demikian, dalam etika identitas ideal Islam, informasi mengenai mekanisme transaksi harus jelas dan menyertakan jenis akad yang digunakan.

Nilai ke empat Fokus kepada tujuan pengembangan dan sosial. Pada praktiknya perbankan syariah diharapkan lebih memperhatikan tanggung jawab secara sosial dibanding dengan keuangan konvensional, seperti yang selalu ditekankan dalam islam, yaitu keadilan sosial. Maka untuk mewujudkan hal itu tugas bank syariah juga mencaku pengelolaan zakat, sedekah dan dana qardh hassan, kesejahteraan karyawan, kepedulian terhadap debitur dan pelayanan publik. Nilai kelima Tunduk kepada tinjauan Dewan Pengawas Syariah (DPS).

Salah satu yang membedakan perbankan syariah dan konvensional adalah adanya Dewan Pengawas Syariah (DPS). Bank syariah memiliki DPS yang yang mengawasi kegiatan operasional, produk dan jasa agar sesuai dengan prinsip dan nilai syariah. Berkaitan dengan identitas etika ideal, 
perbankan syariah diharapkan untuk mengungkapkan informasi mengenai pihak-pihak yang berada di jajaran Dewan Pengawas Syariah (DPS). Berdasarkan lima nilai tersebut terbentuklah delapan dimensi Ethical Identity Index yang harus diungkapkan oleh perbankan Syariah yaitu: Pernyataan visi dan misi, Informasi direksi dan manajemen atas, Produk dan jasa; zakat, sedekah dan qardh Hassan, Komitmen terhadap karyawan, Komitmen terhadap debitur, Komitmen terhadap masyarakat, Informasi Dewan Pengawas Syariah (DPS).

\subsection{SHARIA COMFIRMITY AND PROFITABILITY}

Kinerja Keuangan Bank menurut Abdullah, (2003) adalah gambaran kondisi keuangan bank pada suatu periode tertentu baik menyangkut aspek penghimpunan dana maupun penyaluran dana yang biasanya diukur dengan indikator kecukupan modal, likuiditas dan profitabilitas bank. Sedangkan menurut Ikatan Akuntansi Indonesia (IAI) adalah kemampuan perusahaan dalam mengelola dan mengendalikan sumber daya yang dimilikinya. Dapat disimpulkan bahwa kinerja keuangan perbankan adalah gambaran kondisi keuangan bank pada satu periode tertentu dalam mengelola keuangannya guna mencapai tujuan yang diinginkan.

Menurut Hameed \& Mohamed (2016) pengukuran kinerja adalah suatu metode untuk mengukur pencapaian perusahaan berdasarkan target yang ditetapkan sebelumnya yang merupakan langkah-langkah pengendalian yang dapat membantu perusahaan untuk meningkatkan kinerja masa depan serta mengidentifikasi kekurangan dari operasi sepanjang tahun keuangan. Maka penting untuk perusahaan dalam memiliki sistem pengukuran kinerja yang baik dan tepat, karena perusahaan harus tetap kompetitif dan kuat secara keuangan. Meilani (2015) menyebutkan bahwa evaluasi kinerja dari institusi keuangan Islam sama pentingnya dengan mengukur pencapaian individu. Hal ini disebabkan oleh peran dan tanggung jawab lembaga-lembaga keuangan Islam tidak hanya terbatas pada kebutuhan keuangan dari berbagai pihak, tetapi prinsip utamanya adalah bagaimana mereka menjalankan bisnis mereka dan tindakan yang digunakan untuk memastikan bahwa semua kegiatan sesuai dengan syariah.

Kuppusamy et al., (2010) melakukan pengukuran kinerja keuangan perbankan syariah dengan menggunakan model Sharia Conformity and Profitability. Model ini merupakan model pengukuran kinerja keuangan untuk bank syariah, karena menggabungkan antara dua indakator yaitu indikator syariah dan konvensional. Indikator syariah diukur menggunakan Sharia Conformity atau kesesuaian syariah. Sedangkan indikator konvensional diukur melalui profitabilitas.

\subsubsection{Sharia Conformity}

Kesesuaian syariah adalah indikator untuk mengukur sejauh mana bank syariah mampu memenuhi kesesuaian terhadap nilai-nilai dan prinsip syariah yang diukur melalui investasi, pendapatan serta bagi hasil. Rasio untuk mengukur indikator Sharia 
Conformity adalah sebagai berikut:

1. Islamic Investment Ratio

Investasi syariah adalah aktifitas perusahaan dalam melakukan pengelolaan dana yang terbebas dari riba, gharar, dan maisyir. Maka rasio ini mengukur sejauh mana bank syariah melakukan transaksi yang halal dibandingkan transaksi yang mengandung riba, gharar dan judi. Rasio investasi syariah dapat diukur melalui perbandingan antara investasi halal dengan total investasi yang dilakukan oleh bank syariah secara keseluruhan (halal dan non halal). Karena tidak menutup kemungkinan perbankan syariah di Indonesia masi melakukan investasi pada bank konvensional. Mengingat bahwa ratarata perbankan syariah di Indonesia berasal dari bank konvensional. Maka nilai yang dihasilkan dari pengukuran rasio invetasi islam merupakan ukuran aspek kehalalan dan keberhasilan pelaksanaan prinsip dasar bank syariah yaitu terbebas dari unsur riba.

2. Islamic Income Ratio

Rasio ini bertujuan untuk mengukur pendapatan yang berasal dari sumber yang halal. Bank syariah mempunyai kewajiban untuk mengungkapkan dengan jujur setiap pendapatan yang masuk kedalam kategori yang dianggap halal, dan mana yang dilarang dalam Islam. Jika bank syariah memperoleh pendapatan dari transaksi non-halal, maka bank harus mengungkapkan informasi seperti jumlah, sumber, bagaimana penentuannya dan prosedur apa saja yang tersedia untuk mencegah masuknya transaksi yang dilarang oleh syariah. Dalam laporan keuangan bank syariah jumlah pendapatan non-halal dapat dilihat dalam laporan sumber dan penggunaan qardh.

3. Profit Sharing Ratio

Bagi Hasil merupakan tujuan utama dari bank syariah, pembiayaan mudharabah dan musyarakah yang disalurkan oleh perbankan mencerminkan pembiayaan bagi hasil sebagai ciri khas tujuan utama bank syariah. Oleh karena itu, penting untuk mengidentifikasi seberapa jauh bank syariah telah berhasil mencapai tujuan eksistensi mereka atas bagi hasil melalui rasio ini. Untuk mengukur seberapa besar bank meyalurkan pembiayaan bagi hasil dihitung menggunakan profit sharing ratio. Menurut Hameed \& Mohamed (2016) pendapatan dari bagi hasil dapat diperoleh melalui dua akad, yang pertama adalah mudaraba yaitu penanaman dana dari pemilik kepada pengelola dana untuk melakukan kegiatan usaha tertentu, dengan pembagian berdasarkan profit and loss sharing. Akad yang kedua adalah musyarakah yaitu perjanjian antara pemilik modal untuk mencampurkan modal mereka pada suatu usaha tertentu dengan pembagian keuntungan yang telah disepakati sebelumnya, dan kerugian ditanggung semua pemilik modal berdasarkan bagian modal masing-masing.

\subsubsection{Profitability}

Profitabilitas berfungsi untuk mengukur seberapa besar bank syariah mampu menghasilkan keuntungan selama periode tertentu. Profitabilitas diukur melalui rasio dibawah ini: 


\section{Return on Asset (ROA)}

Rasio ini menunjukan keefektifan manajemen dalam mengelola neraca perusahaan. Dalam pengukurannya rasio ini membandingkan pendapatan bersih dengan rata-rata total aset untuk mengukur sejauh mana asset perusahaan bisa menghasilkan laba perusahaan.

2. Return on Equity (ROE)

Rasio adalah untuk mengukur sejauh mana modal perusahaan bisa menghasilkan laba bagi perusahaan. Diukur dengan membandingkan pendapatan bersih terhadap modal investor yang ada.

3. Profit Margin

Rasio ini berfungsi untuk mengetahui sebrapa besar pendapatan bersih yang diterima oleh perusahaan. Diukur dengan membandingkan pendapatan bersih dengan pendapatan yang diterima.

Dalam penelitian Kuppusamy et al., (2010) model SCNP membagi empat kuadran yang merefleksikan kinerja bank syariah. Kuadran-kuadran tersebut yang akan menentukan tingkat kesuaian syariah dan profitabilitas. Keempat kuadran tersebut adalah Upper Right Quadrant (URQ), Lower Right Quadrant (LRQ), Upper Left Quadrant (ULQ), Lower Left Quadrant (LLQ). Kuadran URQ menggambarkan bahwa bank syariah memiliki tingkat kesesuaian syariah serta profitabilitas yang tinggi. Kuadran LRQ menggambarkan bahwa bank syariah memiliki tingkat kesesuaian syariah yang tinggi akan tetapi profitabilitas yang rendah. Sedangkan kuadran ULQ menggambarkan bahwa bank syariah memiliki tingkat kesesuaian syariah yang rendah dengan profitabilitas yang tinggi. Terakhir, kuadran LLQ menggambarkan bahwa bank syariah memiliki tingkat kesuaian syariah dan profitabilitas yang sama-sama rendah.

\subsection{PENGEMBANGAN HIPOTESIS}

Identitas etika perbankan syariah akan memberikan pengaruh pada kepercayaan stakeholder termasuk nasabah (Ariyanto, 2014). Hal ini dikarenakan nasabah perbankan Syariah memiliki persepsi bahwa perbankan Syariah selain berorientasi profit namun juga tetap mengedepankan nilai-nilai Syariah dalam setiap operasionalnya. Sehingga perbankan Syariah dengan identitas etika yang baik akan memiliki kinerja yang baik pula. Hal ini juga didukung oleh penelitian Falikhatun \& Assegaf (2012) bahwa implementasi prinsip-prinsip syariah berpengaruh terhadap kesehatan perbankan syariah di Indonesia. Kemudian penelitian Ariyanto (2014) juga menyimpulkan bahwa pengungkapan identitas etika Islam memiliki pengaruh positif terhadap kinerja keuangan perbankan syariah.

Selanjutnya penelitian yang dilakukan oleh Zaki et al., (2014) menganalisis pengaruh tingkat identitas etika dengan kualitas laporan keuangan dengan mengambil sampel dari bank Islam di asia. Hasil dari penelitian tersebut menunjukkan bahwa dari delapan dimensi Ethical Identity Index, hanya dua dimensi yang yang berpengaruh terhadap kinerja keuangan yang diukur menggunakan Return on Asset (ROA). Perbankan Syariah 
diharapkan tidak hanya berfokus pada keuntungan saja namun juga mengutamakan kegiatan operasional yang bertumpu pada nilai-nilasi Syariah. Sehingga identitas etika yang ditunjukkan oleh perbankan Syariah mampu memberikan pengaruh positif pada kinerja keuangan maupun kinerja Syariah perbankan Syariah. Berdasarkan uraian tersebut maka hipotesis dalam penlitian ini adalah

H1: Ethical Identity berpengaruh terhadap kinerja Syariah Conformity and Profitability.

\section{METODE PENELITIAN}

Penelitian ini mengunakan Sampel bertujuan (purposive sample) dalam pemilihan sample. Sample bertujuan adalah teknik pengumpulan sumber informasi yang tersedia secara tepat dimaksudkan untuk mengoptimalkan informasi dari target yang lebih spesifik, atau sesuai dengan kriteria yang diinginkan oleh peneliti. Kriteria yang digunakan dalam pemilihan sampel adalah

a. Bank Umum Syariah yang terdaftar dalam Otoritas Jasa Keuangan

b. Bank Umum Syariah memiliki laporan tahunan dan keuangan untuk periode 2014-2017.

Variabel dependen dalam penelitian ini adalah model pengukuran kinerja keuangan yaitu Sharia Conformity and Profitability (SCNP). Model pengukuran SCNP yang diformulasikan oleh Kuppusamy et all., ini mengukur kinerja keuangan dengan menggunakan dua variabel. Variabel yang pertama diukur dari sisi syariah yaitu dengan rasio Sharia Conformity (kesesuaian syariah) sedangkan yang kedua diukur dari sisi konvensional yaitu rasio profitability.

\subsection{SHARIA CONFORMITY}

Berdasarkan model SCNP ketaatan syariah diukur menggunakan tiga rasio, yaitu:

\subsubsection{Islamic Investment Ratio}

Rasio investasi halal adalah rasio yang menunjukan presentase dari investasi yang dilakukan oleh bank syariah pada produk-produk halal. Rasio ini merupakan ukuran aspek kehalalan dan keberhasilan pelaksanaan prinsip dasar bank syariah, yakni bebas dari unsur maysir, gharar, dan riba serta aliran dana hanya disalurkan ke sektor yang halal. Rasio ini dapat dihitung dengan rumus sebagai berikut:

$$
\text { Islamic Investment }=\frac{\text { Islamic Investment }}{\text { Islamic Investment }+ \text { Non Islamic Investment }}
$$

\subsubsection{Islamic Income Ratio}


Rasio pendapatan halal menunjukkan persentase dari seberapa banyak pendapatan yang berasal dari sumber halal yang didapatkan dibandingkan dengan total pendapatan yang diperoleh bank syariah. Dalam laporan keuangan bank syariah jumlah pendapatan non-halal dapat dilihat dalam laporan sumber dan penggunaan qardh. Perhitungan untuk rasio ini adalah sebagai berikut:

$$
\text { Islamic Income }=\frac{\text { Islamic Income }}{\text { Islamic Income }+ \text { Non Islamic Income }}
$$

\subsubsection{Profit Sharing Ratio}

Rasio ini mengukur seberapa besar bank syariah mampu menyalurkan dana ke sektor produktif dengan skema bagi hasil. Perhitungan rasio ini didapatkan dari total pembiayaan mudharabah dan musyarakah yang dibagi dengan total pembiayaan. Formula rasio profit sharing ratio adalah sebagai berikut:

$$
\text { Profit Sharing Ratio }=\frac{\text { Pembiayaan Mudharabah }+ \text { Musyarakah }}{\text { Total Financing }}
$$

\subsection{PROFITABILITY}

Profitabilitas dalam model SCNP diukur menggunakan tiga rasio keuangan, diantaranya:

\begin{tabular}{lc}
\hline Return of Asset (ROA) & $R O A=\frac{\text { Net Income }}{\text { Total Asset }}$ \\
\hline Return of Equity (ROE) & $R O E=\frac{\text { Net Income }}{\text { Stockholder's Equity }}$ \\
\hline Net Profit Matgin (NPM) & $N P M=\frac{\text { Net Income }}{\text { Total Operating Revenue }}$ \\
\hline
\end{tabular}

Setelah masing-masing rasio dihitung selanjutnya menghitung ratarata dari masing-masing variabel. Rumus untuk variabel ketaatan syariah dan profitabilitas adalah sebagai berikut:

$$
\overline{S C}=\frac{R 1+R 2+R 3}{3} \text { dan } \overline{P R}=\frac{R 1+R 2+R 3}{3}
$$

$\overline{S C}=$ Rata-rata rasio dari variabel sharia conformity

$\overline{P R}=$ Rata-rata rasio dari variabel profitability

R1 = Rasio pertama dari variabel sharia conformity atau profitability

R2 = Rasio kedua dari variabel sharia conformity atau profitability

R3 = Rasio ketiga dari variabel sharia conformity atau profitability

Kemudian dalam menilai kinerja keuangan dengan model sharia conformity and profitability diukur oleh masing-masing nilai dari kedua aspek. Terdapat 3 penilaian dalam menentukan pengukuran nilai sharia conformity and profitability: 
a. Memberikan angka 3 apabila sharia conformity and profitability bernilai positif.

b. Memberikan angka 2 apabila sharia conformity positif dan profitability negatif, atau sharia conformity negatif dan profitability positif.

c. Memberikan angka 1 apabila sharia conformity and profitability bernilai negatif.

Variabel independen dalam penelitian ini adalah Ethical Identity dan ukuran perusahaan. Variabel ethical identity diukur menggunakan Ethical Identity Index yang dikembangkan oleh Haniffa \& Hudaib (2007). Ethical identity index merupakan ukuran yang digunakan untuk mengetahui sejauh mana tingkat kesesuaian antara yang diungkapkan perusahaan melalui laporan tahunan dengan kondisi ideal dari ethical identity berdasarkan kerangka bisnis yang beretika Islam (Haniffa \& Hudaib, 2007). Penelitian menggunakan checklist yang terdiri dari lima tema dan delapan dimensi yang seharusnya diungkapkan dalam laporan tahunan bank Syariah untuk menunjukkan nilai-nilai etika perbankan syariah. Ethical identity index meliputi delapan dimensi yang meliputi dimensi pernyataan visi dan misi, dimensi dewan komisaris dan manajemen puncak, dimensi produk dan layanan, dimensi zakat, sedekah dan pinjaman kebajikan, dimensi komitemen terhadap karyawan, dimensi komitmen terhadap debitur, dimensi komitmen terhadap masyarakat, dan dimensi dewan pengawas Syariah. Pemberian skor pada setiap indikator yang terdapat pada laporan tahunan menggunakan skala dichotomous. Dimana poin penilaian menggunakan scoring dari 0-1, dimana jika;

a. Poin satu jika indikator diungkapkan dalam laporan tahunan

b. Poin nol jika indikator tidak diungkapkan dalam laporan tahunan

Kemudian skor dari masing-masing indikator dijumlahkan. Yang mana jumlah maksimal yang dicapai adalah 78. Adapun menyatakan nilai indeks dalam bentuk sebagai berikut:

$$
E I I j=\frac{\sum_{t=1}^{n j} X i j}{n j} \times 100 \%
$$

Keterangan:

$\mathrm{EIIj}=$ Ethical Identity Index

Xij = Jumlah indikator diungkapkan oleh perusahaan pada masingmasing dimensi

nj = Jumlah indikator ideal yang harus diungkapkan pada masingmasing dimensi

Penelitian ini menggunakan variabel control ukuran perusahaan. Ukuran perusahaan merupakan suatu skala untuk menunjukan besar atau kecilnya sebuah perusahaan dengan melihat total aset yang dimiliki. Ukuran perusahaan cenderung identik dengan kemampuan perusahaan dalam 
mengelola perusahaan guna pencapaian kinerja yang diharapkan (Ariyanto, 2014). Ukuran bank syariah diukur berdasarkan total aset dibagi dengan total pendapatan.

Model matematis dapat di identifikasikan dari persamaan berikut:

$$
\text { SCNPit }=\alpha i t+\beta 1 \text { EIIit }+\beta 1 \text { Sizeit }+e \text { it }
$$

$\begin{array}{ll}\text { EII } & =\text { Pengungkapan Ethical Identity Index } \\ \text { A } & =\text { Konstanta } \\ \text { B } & =\text { Koefisien regresi } \\ \text { SCNP } & =\text { Syariah Conformity and Profitability } \\ \text { Size } & =\text { Ukuran perusahaan }\end{array}$

\section{HASIL DAN DISKUSI}

\subsection{ANALISIS DESKRIPTIF}

Statistik deskriptif diperlukan untuk menjelaskan sampel yang dalam penelitian. Dijelaskan berdasarkan nilai rata-rata, nilai minimum, nilai maksimum, dan standar deviasi dari sampel penelitian. Terdapat dua variabel dalam penelitian ini yaitu Ethical Identity sebagai variabel bebas dan kinerja keuangan Bank Umum Syariah sebagai variabel terikat. Untuk Variabel terikat diukur oleh model pengukuran Sharia Conformity and Profitability.

Tabel 1. Deskriptif Statistik

\begin{tabular}{lccrrr}
\hline \multicolumn{1}{c}{ Variabel } & N & Mean & Min & Max & Std. deviasi \\
\hline EII & 48 & 0.7142094 & 0.525641 & 0.8589744 & 0.833788 \\
\hline SCNP & 48 & 28.125 & 2 & 3 & 0.3944428 \\
\hline $\begin{array}{l}\text { Ukuran } \\
\text { Perusahaan }\end{array}$ & 48 & 0.1253899 & 0.0340747 & 0.3948051 & 0.856423 \\
\hline EII = Ethical Identity Index \\
\hline \multicolumn{5}{l}{ SCNP = Sharia Conformity and Profitability } \\
\hline
\end{tabular}

4.2 KINERJA SCNP PERBANKAN SYARIAH PERIODE 2014-2017

Berdasarkan hasil perhitungan atas kinerja SCNP perbankan Syariah pada periode 2014-2017 disajikan dalam Tabel 2.

Secara umum pada tahun 2014 dapat dikatakan bahwa pada tahun 2014 Bank Umum Syariah memiliki nilai ketaatan Syariah yang baik karena semua nilai skor shariah conformity (SC) bernilai positif dengan nilai SC tertinggi yaitu BJB Syariah dan nilai SC terendah adalah, namun dari sisi BTPN Syariah. Sedangkan jika dilihat dari nilai profitabilitasnya dua bank memiliki nilai negative yaitu BSM dan Viktoria Syariah. Nilai profitabilitas tertinggi dimiliki oleh Maybank Syariah. 
Tabel 2. Kinerja SCNP perbankan syariah peridoe 2014-2017

\begin{tabular}{|c|l|c|c|c|c|c|c|c|c|}
\hline \multirow{2}{*}{ No } & \multirow{2}{*}{ BUS } & \multicolumn{2}{|c|}{2014} & \multicolumn{2}{|c|}{2015} & \multicolumn{2}{|c|}{2016} & \multicolumn{2}{|c|}{2017} \\
\cline { 2 - 10 } & & SC & P & SC & P & SC & P & SC & P \\
\hline 1 & BSM & 0,74 & $-0,01$ & 0,75 & 0,04 & 0,77 & 0,04 & 0,79 & 0,04 \\
\hline 2 & BCA Syariah & 0,82 & 0,06 & 0,82 & 0,06 & 0,83 & 0,08 & 0,83 & 0,09 \\
\hline 3 & Mega Syariah & 0,67 & 0,01 & 0,67 & 0,01 & 0,69 & 0,09 & 0,71 & 0,07 \\
\hline 4 & BJB Syariah & 0,99 & 0,03 & 0,96 & 0,01 & 0,96 & $-0,38$ & 0,96 & 0,38 \\
\hline 5 & BRI Syariah & 0,77 & 0,00 & 0,79 & 0,04 & 0,79 & 0,05 & 0,54 & 0,03 \\
\hline 6 & BTPN Syariah & 0,67 & 0,09 & 0,67 & 0,13 & 0,67 & 0,22 & 0,67 & 0,26 \\
\hline 7 & Bukopin Syariah & 0,80 & 0,02 & 0,83 & 0,05 & 0,84 & $-0,08$ & 0,87 & 0,00 \\
\hline 8 & Maybank Syariah & 0,72 & 0,19 & 0,69 & $-0,93$ & 0,69 & $-0,57$ & 0,69 & 0,24 \\
\hline 9 & Muamalat & 0,84 & 0,01 & 0,85 & 0,02 & 0,85 & 0,02 & 0,83 & 0,01 \\
\hline 10 & Panin Syariah & 0,96 & 0,07 & 0,97 & 0,05 & 0,95 & 0,02 & 0,95 & $-0,76$ \\
\hline 11 & Victoria Syariah & 0,85 & $-0,12$ & 0,89 & $-0,13$ & 0,93 & $-0,14$ & 0,91 & 0,02 \\
\hline 12 & BNI Syariah & 0,72 & 0,09 & 0,73 & 0,10 & 0,74 & 0,11 & 0,74 & 0,10 \\
\hline
\end{tabular}

Kondisi tahun 2015 dari sisi SC semua BUS memiliki nilai yang baik karena memiliki nilai SC positif. Nilai SC tertinggi dimiliki oleh bank panin Syariah dan nilai terendah bank mega Syariah, sedangkan jika dilihat dari sisi profitabilitasnya terdapat dua BUS dengan nilai negative yaitu Maybank Syariah dan Victoria Syariah.

Kondisi yang sama juga terjadi pada tahun 2016, karena seluruh BUS memperlihatkan nilai SC yang positif dengan nilai tertinggi adalah BJB Syariah dan nilai terendah adalah BTPN Syariah. Dari sisi profitabilitas kondisi pada tahun 2016 lebih buruk dibandingkan tahun 2015 karena terdapat empat bank yang memiliki nilai profitabilitas negative yaitu BJB Syariah, Bukopin Syariah, Maybank Syariah, dan Victoria Syariah. Sedangkan BUS dengan nilai Profitabilitas terbaik adalah BTPN Syariah.

Pada tahun 2017 BUS menunjukkan nilai SC yang baik karena seluruh BUS sampel memiliki nilai positif dengan nilai tertinggi BJB Syariah dan nilai terendah adalah BRI Syariah. Kondisi profitabilitas BUS pada tahun 2017 lebih baik dibandingkan dengan kondisi tahun 2016. Hanya ada satu BUS yang memiliki nilai negative yaitu Bank Panin Syariah. Sedangkan BUS dengan nilai profitabilitas tertinggi adalah BJB Syariah.

\subsection{PENGUJIAN HIPOTESIS}

Pengujian hipotesis dilakukan untuk mengetahui apakah terdapat pengaruh antara variabel independen dengan variabel dependen. Pengujian hipotesis dilakukan dengan tiga cara yakni Uji Statistik F, Uji Statistik t dan Uji Koefisien Determinasi. Pada penelitian ini, ketiga pengujian dilakukan dengan menggunakan hasil dari Common Effect Model (CEM). Hasil pengujian hipotesis dirangkum pada Tabel 3. 
Uji $\mathrm{t}$ digunakan untuk menilai apakah variabel independen berpengaruh terhadap variabel dependen. Hubungan tersebut dilihat dari nilai signifikansi ( $t$-value) dan membandingkannya dengan alpha $(\alpha=0.05)$, apabila nilai signifikansi lebih kecil dari alpha berarti terdapat pengaruh yang signifikan.

Tabel 3. Hasil Pengujian Hipotesis

\begin{tabular}{lcr}
\hline Variabel & Koefisien & p-value \\
\hline Konstanta & 1.291195 & 0,005 \\
\hline EII & 2.059966 & 0,001 \\
\hline Size & 0.3992177 & 0,507 \\
\hline F-statik & \multicolumn{2}{c}{0,0037} \\
\hline R-square & 0,1890 \\
\hline
\end{tabular}

Berdasarkan Tabel 3 nilai signifikansi variabel bebas adalah sebesar 0.001 yang mana lebih kecil dari 0.05 , hal ini menunjukan bahwa variabel ethical identity mempengaruhi variabel terikat secara signfikan. Akan tetapi nilai signifikansi variabel kontrol yang diukur dengan ukuran perusahaan menunjukan angka 0.507 yang artinya tidak mempengaruhi variabel terikat secara signifikan.

Uji $F$ digunakan untuk melihat nilai signifikasi dari setiap variabel secara simultan dan serentak. Tabel 3 menunjukkan nilai $\mathrm{F}$ statistik adalah sebesar 0.0037 yang lebih kecil dari nilai signifikansi yaitu 0.05. Hal ini menunjukkan bahwa variabel independen dalam penelitian ini secara bersama-sama berpengaruh terhadap variabel dependen.

Uji Koefisien Determinasi $\left(\mathrm{R}^{2}\right)$ adalah untuk menunjukkan seberapa besarvariasi variabel dependen dapat diterangkan oleh variabel independen. Dengan demikian dapat diketahui besaran pengaruh antara variabel dependen dan independen. Dilihat dari r-square pada Tabel 3 menunjukan bahwa secara keseluruhan variabel terikat yaitu kinerja keuangan yang diukur dengan sharia conformity and profitability (SCNP) dapat dijelaskan oleh variabel bebas yaitu ethical identity adalah sebesar 0.1890 atau sebesar $18.90 \%$ sisanya yaitu sebsar $81.1 \%$ dijelaskan diluar model ini.

\subsection{ETHICAL IDENTITY INDEX TERHADAP SHARIA CONFORMITY AND PROFITABILITY}

Hipotesis dalam penelitian ini adalah ethical identity index (EII) berpengaruh positif terhadap kinerja keuangan dengan model sharia conformity and profitability (SCNP). Berdasarkan Tabel 3 diperoleh koefisien 2.059966 dengan nilai signifikasinya 0,001 sehingga hipotesis diterima. Sehingga dapat disimpulkan bahwa pengungkapan EII berpengaruh secara positif terhadap SCNP.

Hasil penelitian ini sejalan dengan penelitian Hameed \& Mohamed (2016) yang menyatakan bahwa kinerja bank syariah dapat meningkat seiring dengan penerapan prinsip syariah. Selain itu penelitian ini juga melengkapi 
penelitian Ariyanto (2014) yang mengatakan bahwa pengungkapan identitas etika islam memiliki pengaruh yang signifikan terhadap kinerja keuangan jika diukur melalui rasio keuangan Return of Asset (ROA) dan Return of Equity (ROE). Asrori (2014) membuktikan bahwa pelaksanaan DPS sebagai dewan penasihat dan pengawas syariah memiliki pengaruh positif terhadap kinerja keuangan bank syariah jika diukur menggunkan rasio profit sharing, ROA, ROE, serta profit margin. Selain itu penelitian Asrori (2014) juga membuktikan bahwa penyaluran dana serta pelayanan jasa perbankan mempengaruhi secara positif kinerja keuangan bank syariah. Kemudian penelitian Wardayati (2011) mengatakan bahwa salah satu faktor utama nasabah menjalin kemitraan dengan bank syariah adalah ketaatan bank syariah terhadap penarapan prinsip-prinsip syariah dalam menjalankan usahanya. Terakhir, penelitian Falikhatun \& Assegaf (2012) membuktikan bahwa perbankan syariah yang telah mengimplementasikan prinsip-prinsip syariah dapat meningkatkan kesehatan finansialnya dan tidak menyebabkan sistem keuangan mengkhawatirkan atau bahkan bangkrut, sehingga perbankan syariah akan memiliki citra positif di masyarakat dan kalangan bisnis.

Hasil dari penelitian ini menunjukan bahwa semakin luas bank syariah dalam mengungkapan identitasnya sebagai bank yang memiliki identitas etika Islam akan menunjukan tingkat penerapan prinsip-prinsip syariah yang baik dalam kegiatan operasionalnya. Kemudian hal ini akan mempengaruhi kinerja keuangan bank syariah, yang disebabkan oleh semakin baik bank syariah dalam membangun citra sebagai bank yang menerapkan prinsipprinsip syariah, maka akan menambah kepercayaan pihak-pihak yang memiliki kepentingan. Maka ketika identitas dan citra bank syariah terbentuk dengan semakin baik akan membuat masyarakat, nasabah, ataupun stakeholder semakin percaya dan mendorong untuk memiliki kegiatan dan berinteraksi dengan bank syariah, pada akhirnya hal ini akan membuat kinerja keuangan bank syariah dapat meningkat.

\subsection{UKURAN PERUSAHAAN DAN SCNP}

Hasil pengujian terhadap variabel control yaitu ukuran perusahaan penelitian ini menunjukkan nilai $p$-value lebih besar dari alpha 5\% yaitu 0.507 dengan koefisien 0.3992. Hal ini menunjukkan bahwa ukuran perusahaan tidak berpengaruh terhadap kinerja SCNP perbankan Syariah. Hasil penelitian ini berbeda dengan penelitian yang dilakukan oleh Akbar (2013). Hal ini dapat disebabkan oleh berbedanya pengukuran kinerja yang digunakan dalam penelitian ini dengan penelitian sebelumnya. Perbankan Syariah sebagai bank yang beroperasi dengan prinsip-prinsip Syariah dituntut untuk menjalankan kegiatan opersaional sesuai dengan Syariah. Sehingga sumber daya yang dimiliki oleh perusahan kecil maupun perusahaan besar tidak mempengaruhi kinerja SCNP. Semua perbankan Syariah tanpa melihat sumber daya yang dimiliki senantiasa untuk menjalankan prinsip-prinsip Syariah ini dan berusaha untuk meningkatkan kinerja profitabilitasnya. 


\section{SIMPULAN}

Penelitian ini bertujuan untuk menganalisis pengaruh ethical identity index terhadap kinerja perbankan Syariah yang diukur dengan SCNP model. Hasil penelitian menunjukkan bahwa ethical identity index berpengaruh positif terhadap kinerja SCNP perbankan syariah. Hal ini menunjukkan bahwa perbankan Syariah yang memiliki komitmen pada nilai-nilai etika Islam mampu meningkatkan kinerja Syariah dan kinerja profitabilitasnya. Sedangkan variabel kontrol ukuran perusahaan tidak berpengaruh terhadap kinerja SCNP. Untuk penelitian selanjutnya dapat menambahkan variabel lain seperti karakteristik top manajemen dan struktur kepemilikan untuk melihat pengaruhnya terhadap kinerja SCNP.

Implikasi dari penelitian ini adalah perbankan Syariah sebaiknya meningkatkan penerapan nilai-nilai etika. Selain itu perbankan syariah juga harus mengungkapkannya penerapan nilai-nilai Syariah tersebut dalam laporan keuangan sebagai bagian dari penyampaian informasi kepada nasabah dan semua stakeholder atas nilai-nilai etika yang dipegang dan diterapkan oleh perbankan Syariah.

\section{DAFTAR PUSTAKA}

Abdullah, M. F. (2003). Manajemen Perbankan. Malang: UMM Press.

Akbar, D. A. (2013). Analisis Pengaruh Ukuran Perusahaan, Kecukupan Modal, Kualitas Aktiva Produktif (KAP) Dan Likuiditas Terhadap Kinerja Keuangan (Studi Kasus Bank Umum Syariah di Indonesia Periode 2007-2011). Jurnal Ilmiah STIE MDP, 3(1), 66-82.

Antonio, M. S. (2001). Bank Syariah: dari Teori ke Praktik. (D. M. H. Basri \& D. Farida R, Eds.) (I). Jakarta: Gema Insani.

Arifin, Z. (2006). Dasar-dasar Manajemen Bank Syariah. Jakarta: Pustaka Alvabet.

Ariyanto, T. (2014). Analisis Pengaruh Pengungkapan Identitas Islam Terhadap Kinerja Keuangan Bank Syariah Di Asia. Jurnal Akuntansi Dan Keuangan (JAKA), 1(1), 98-110.

Asrori. (2014). Implementasi Islamic Corporate Governance dan Implikasinya Terhadap Kinerja Bank Syariah. Jurnal Dinamika Akuntansi, 6(1), 90-102.

Berrone, P., Surroca, J., \& Tribó, J. A. (2007). Corporate ethical identity as a determinant of firm performance: A test of the mediating role of stakeholder satisfaction. Journal of Business Ethics, 76(1), 35-53. https://doi.org/10.1007/s10551-006-9276-1

Deegan, C. (2002). Introduction: The legitimising effect of social and environmental disclosures - a theoretical foundation. Accounting, 
Auditing \& Accountability Journal (Vol. 15). https://doi.org/10.1108/09513570210435852

Falikhatun, \& Assegaf, Y. U. (2012). Bank Syariah Di Indonesia : Ketaatan Pada Prinsip-Prinsip Syariah Dan Kesehatan Finansial. Conferene in Business, Accounting and Management-FE UNISSULA, 1 No. 1(Desember), 245-254.

Fauziyah, Y., \& Siswantoro, D. (2016). Analisis Pengungkapan Identitas Etika Islam dan Kinerja Keuangan Perbankan Syariah di Indonesia. Simposium Nasional Akuntansi XIX, (August), 1-19.

Gray, R., Javad, M., Power, D. M., \& Sinclair, C. D. (2001). Social and environmental disclosure and corporate characteristics: A research note and extension. Journal of Business Finance and Accounting, 28(3-4), 327-356. https://doi.org/10.1111/1468-5957.00376

Hameed, S., \& Mohamed, B. (2016). Alternative Disclosure \& Performance Measures for Islamic, (June 2016).

Haniffa, R., \& Hudaib, M. (2007). Exploring the ethical identity of Islamic Banks via communication in annual reports. Journal of Business Ethics, 76(1), 97-116. https://doi.org/10.1007/s10551-006-9272-5

Kuppusamy, M., Saleh, A. S., \& Samudhram, A. (2010). Measurement of Islamic banks performance using a shariah conformity and profitablity model. Review of Islamic Economics, 13(2), 35-48.

Muhibbai, A., \& Basri, H. (2017). Pengaruh Pengungkapan Identitas Etis Islam, Agency Cost Dan Modal Intelektual Terhadap Kinerja Keuangan (Studi Pada Bank Umum Syariah Periode 2010-2014). Jurnal Ilmiah Mahasiswa Ekonomi Akuntansi, 2(1), 30-37.

Roberts, P. W., \& Dowling, G. R. (2002). Corporate reputation and sustained superior financial performance. Strategic Management Journal, 23(12), 1077-1093. https://doi.org/10.1002/smj.274

Sayekti Endah Retno Meilani. (2015). Hubungan Penerapan Good Governance Business Syariah Terhadap Islamicity Financial Performance Index Bank Syariah Di Indonesia. Athenea Digital, (18), 85-90.

Vera Zelenović, P., \& Davidović, M. (2011). Corporate Identity of Banks In A Function of Market Competitivenes. In International Symposium Engineering Management And Competitiveness 2011.

Wardayati, S. M. (2011). Implikasi Shariah Governance Terhadap Reputasi Dan Kepercayaan Bank Syariah. Walisongo: Jurnal Penelitian Sosial Keagamaan, 19(1), 1. https://doi.org/10.21580/ws.2011.19.1.210

Zaki, A., Sholihin, M., \& Barokah, Z. (2014). The association of Islamic bank ethical identity and financial performance: evidence from Asia. 
Asian Journal of Business Ethics, 3, 97-110. https://doi.org/10.1007/s13520-014-0034-7 
